\title{
Komunikat: Przyznanie dofinansowania na projekt badawczy „Polski Atlas Etnograficzny - opracowanie naukowe, elektroniczny katalog danych, publikacja zasobów w sieci Internet, etap II"
}

Tematyka zachowania dziedzictwa kulturowego społeczności wiejskich staje się coraz częściej przedmiotem zainteresowania polskich etnologów. Podejmowane przez nich działania dotyczą różnych obszarów kraju i oprócz badań terenowych wymagają również rozbudowanych kwerend źródłowych. Od wielu lat tego typu poszukiwania materiałowe odbywają się w cieszyńskiej pracowni Polskiego Atlasu Etnograficznego (dalej: PAE), obecnie włączonej w strukturę Wydziału Sztuki i Nauk o Edukacji Uniwersytetu Śląskiego w Katowicach. Jest to jedyne archiwum etnograficzne stanowiące pokłosie ogólnopolskich badań atlasowych prowadzonych w systematyczny sposób w drugiej połowie XX wieku. Prace nad realizacją PAE wciąż trwają, choć w nieco zmodyfikowanej formie ${ }^{1}$.

Wyniki dotychczasowych badań atlasowych nie są wszystkim dostatecznie znane. Wiele z nich wciąż jest trudno dostępnych dla naukowców, regionalistów czy pasjonatów polskiej kultury wiejskiej. Zasoby źródłowe PAE, mozolnie zbierane przez kilka ostatnich dekad, obejmują kilkadziesiąt metrów bieżących materiałów etnograficznych, w tym ankiety i kwestionariusze wywiadu, mapy, fotografie oraz zróżnicowaną dokumentację aktową. Większość z tych zbiorów warta jest szerszej prezentacji, jednak wymaga to wpierw wieloletnich prac inwentaryzacyjnych, konserwacyjnych i digitalizacyjnych. Ten proces już trwa, o czym dalej.

${ }^{1}$ O specyfice prac badawczych PAE w ostatnich latach napisano sporo (zob. np. Z. KŁoDNICKI: Polski atlas etnograficzny - historia, stan obecny i perspektywy. „Lud” 2001, t. 85, s. 239-275; IDEM: Polski atlas etnograficzny - stan prac. „Ethnologia Europae Centralis” 2005, t. 7, s. 100-105; Z. KŁodnicki, A. Pieńczak, J. Koźmí́ska: „Polski atlas etnograficzny”. Historia, osiagnięcia, perspektywy badawcze. Katowice 2017 (Biblioteka Polskiego Atlasu Etnograficznego. T. 1). 
Przed kilku laty w ramach pionierskiego projektu „Polski Atlas Etnograficzny opracowanie naukowe, elektroniczny katalog danych, publikacja zasobów w sieci Internet, etap I"2 powstała specjalna platforma prezentacji treści atlasowych, o nazwie Cyfrowe Archiwum Polskiego Atlasu Etnograficznego (zob. www.archiwumpae.us.edu.pl). Znajduje się na niej ponad 14000 kart obiektów, tworzących trzy obszerne kolekcje danych etnograficznych pozyskanych w ramach działalności atlasowej. Kolekcje obejmują: ponad 470 ankiet dotyczących zbieractwa w celach pokarmowych i leczniczych roślin dziko rosnących (lata 1947-1953), 12181 niepublikowanych fotografii, wykonanych w trakcie ogólnopolskich badań terenowych (1954-1971), oraz 770 map opublikowanych do tej pory w zeszytach Polskiego atlasu etnograficznego (1958-1971) i tomach z serii „Komentarzy do Polskiego Atlasu Etnograficznego" (1999-2013). Zakończony w 2018 roku projekt przyniósł wiele innych wymiernych wyników naukowych oraz dydaktycznych ${ }^{3}$. Sporo materiałów zgromadzonych $\mathrm{w}$ cieszyńskiej pracowni atlasowej wymaga jednak dalszego opracowania naukowego. Szczególnie cenną inicjatywą $\mathrm{w}$ dobie zainteresowania badaczy tzw. niematerialnym dziedzictwem kulturowym byłaby digitalizacja i udostępnienie w Cyfrowym Archiwum Polskiego Atlasu Etnograficznego ponad 1000 kwestionariuszy PAE poświęconych obrzędowości weselnej, urodzinowej oraz pogrzebowej ${ }^{4}$. W 2018 roku rozpoczęto zatem starania mające na celu kontynuację rozpoczętych z sukcesem działań digitalizacyjnych.

Końcem listopada 2019 roku, niemal dwa lata po zakończeniu pierwszej edycji projektu, rozstrzygnięto kolejny konkurs Ministerstwa Nauki i Szkolnictwa Wyższego w ramach programu NPRH (moduł: „Dziedzictwo narodowe”), w którym ocenie poddano 135 wniosków. Projekt „Polski Atlas Etnograficzny - opracowanie naukowe, elektroniczny katalog danych, publikacja zasobów w sieci Internet, etap II" znalazł się w grupie 15 najwyżej ocenionych, z dofinansowaniem w wysokości 513441 złotych $^{5}$.

Czteroletni grant ministerialny obejmuje różnorodne cele i zadania badawcze, realizowane głównie w cieszyńskiej Pracowni Digitalizacyjnej Polskiego Atlasu Etnograficznego (powstałej w 2015 roku w ramach pierwszej edycji projektu).

${ }^{2}$ Projekt, realizowany wspólnie z Polskim Instytutem Antropologii, był finansowany w latach 2014-2018 z budżetu Ministerstwa Nauki i Szkolnictwa Wyższego w ramach III edycji Narodowego Programu Rozwoju Humanistyki (11H 130162 82).

${ }^{3}$ Szerzej, zob. Z. KŁodnicki, A. PieńcZak, J. Koźmińska: „Polski atlas etnograficzny”..., s. 99-154; A. PieńczaK: Sprawozdanie z realizacji projektu „Polski Atlas Etnograficzny - opracowanie naukowe, elektroniczny katalog danych, publikacja zasobów w sieci Internet, etap I”. „Studia Etnologiczne i Antropologiczne" 2018, t. 18, s. 259-263.

${ }^{4}$ Szerzej zob. A. Pıińczak: Cyfrowe Archiwum Polskiego Atlasu Etnograficznego - możliwości wyszukiwawcze i dalsze perspektywy badawcze. „Lud” 2019, t. 103, s. 208-229.

${ }^{5}$ Projekt realizowany wspólnie z Polskim Instytutem Antropologii, sfinansowany zostanie w latach 2020-2024 z budżetu Ministerstwa Nauki i Szkolnictwa Wyższego w ramach Narodowego Programu Rozwoju Humanistyki (wkrótce zostanie podpisana umowa). Zob. https://www.gov.pl/ web/nauka/ogloszenie-wynikow-konkursu-dziedzictwo-narodowe-ii2018 [data dostępu: 30.11.2019]. 
Przedsięwzięcie po raz kolejny wymaga między innymi analizy ilościowej i jakościowej kilkutysięcznych zasobów archiwalnych PAE, stworzenia merytorycznej koncepcji ich opracowania naukowego, wielomiesięcznej redakcji cyfrowej oraz opracowania uzyskanych wyników w formie publikacji. W drugiej edycji zakłada się opracowanie trzech kolekcji etnograficznych, obejmujących szacunkowo 1400 niepublikowanych fotografii wykonanych przez dr hab. Zygmunta Kłodnickiego (obecnie emerytowanego prof. UŚ) w trakcie badań terenowych (lata sześćdziesiąte XX wieku) ${ }^{6}$ oraz blisko 700 obszernych kwestionariuszy PAE poświęconych obrzędowości narodzinowej i pogrzebowej (lata siedemdziesiąte $\mathrm{XX}$ wieku). Oprócz tego planowana jest modernizacja dotychczasowego interfejsu strony internetowej oraz dalsze prace introligatorskie dotyczące kilkuset kwestionariuszy PAE poświęconych kulturze materialnej. Prace te umożliwią $\mathrm{w}$ przyszłości opracowanie naukowe oraz digitalizację kolejnych unikatowych zbiorów zdeponowanych w cieszyńskiej pracowni atlasowej.

W projekcie uczestniczy wyspecjalizowana kadra naukowa doświadczona $\mathrm{w}$ pracach zarówno atlasowych, jak i cyfryzacyjnych. Kompetentnym zespołem wykonawców ponownie kieruje dr hab. Agnieszka Pieńczak, prof. UŚ (badaczka od blisko dwudziestu lat uczestnicząca w badaniach atlasowych). Zespół tworzą: dr hab. Zygmunt Kłodnicki, em. prof. UŚ (wieloletni redaktor PAE i licznych tomów „Komentarzy do Polskiego Atlasu Etnograficznego”), mgr Joanna Koźmińska (przedstawicielka Polskiego Instytutu Antropologii mająca spore osiągnięcia w cyfryzacji dorobku polskiej etnologii i antropologii kulturowej), dr Bartłomiej Chromik (doświadczony badacz języka i kultury wilamowskiej oraz stosowania metod informatycznych $\mathrm{w}$ etnologii), informatycy i digitaliści uczestniczący w pierwszej edycji projektu - mgr inż. Krzysztof Kasprzyński, inż. Krystian Firla, inż. Sławomir Szewieczek. Zostanie też zatrudniona osoba na stanowisko asystenta.

Omawiany projekt ma pierwszorzędne znaczenie dla przyszłych badań naukowych dotyczących kultury wiejskiej drugiej połowy XX wieku. Uzyskane na jego podstawie wyniki, ze względu na niezaprzeczalną wartość dokumentacyjną oraz unikatowość analizowanych zbiorów, mogą być przydatne poznawczo dla przedstawicieli różnych nauk i dyscyplin, głównie humanistycznych i społecznych.

Agnieszka Pieńczak

\footnotetext{
${ }^{6}$ Obecnie trwają prace nad inwentaryzacją kolekcji; liczba zdjęć może być zatem większa.
} 